\title{
Characteristics of flow and heat transfer in rotor- pulsation apparatus during delignification of wheat straw in technology of bioethanol production
}

\author{
Borys Davydenko, Oleksandr Obodovych, Vitalii Sydorenko
}

\author{
Institute of Engineering Thermophysics of NAS of Ukraine
}

Keywords:
Wheat straw
Delignification
Rotor-pulsation
apparatus
Energy dissipation

Article history:

Received 03.08.2020

Received in revised

form 22.11.2020

Accepted 25.03.2021

Corresponding

author:

Vitalii Sydorenko

E-mail:

vrangel08@i.ua

DOI: $10.24263 / 2304-$

974X-2021-10-1-15

\section{Abstract}

Introduction. Improving the efficiency of pretreatment of lignocellulosic raw materials is the use of physical effects that occur during the movement of viscous fluid in rotary pulsation apparatus. The aim of the research is the degree of delignification of lignocellulosic raw materials and the theoretical substantiation of its temperature increase by processing in a rotor-pulsation apparatus.

Materials and methods. The raw material for the research was wheat straw. The amount of lignin isolated was determined by the weight method. Simulation of fluid flow and heat transfer in the rotor-pulsation apparatus was performed by numerical method.

Results and discussion. It was determined that the treatment of the aqueous dispersion of straw in a ratio of 1:10 due to energy dissipation for 70 minutes leads to the release of $42 \%$ lignin. Changing the water/solid ratio from $1: 10$ to $1: 5$ leads to an increase in the percentage yield of lignin to $58 \%$.

The results of experimental and numerical studies have shown that when processing an aqueous dispersion of straw in a rotary pulsation apparatus, this raw material for a certain period of time is heated to a temperature at which the intensive release of lignin. The changes in time of the temperature of the aqueous dispersion of straw during its processing in the rotary pulsation apparatus indicate the possibility of using rotary pulsation apparatus for heating the raw material intended for hydrolysis, instead of using external energy sources.

The results of computational studies of the dynamics of changes in the temperature of the aqueous dispersion of straw during its processing in a rotor-pulsation apparatus were compared with the results of experimental studies. Satisfactory agreement of experimental and calculated results is obtained.

Conclusions. According to the results of numerical studies of hydrodynamics and heat transfer in the rotorpulsation apparatus, the possibility of raising the temperature of the raw material intended for hydrolysis to the required level after its processing in this apparatus has been established. It is determined that the change of the hydraulic module leads to an increase in lignin yield. 


\section{Introduction}

The production of bioethanol from lignocellulosic raw materials has both a number of advantages and disadvantages compared to traditional raw materials containing starch.

Cellulosic feedstocks offer several advantages over starch- and sugar-based feedstocks. They are either waste products or purposefully grown energy crops harvested from marginal lands not suitable for other crops. Less fossil fuel energy is required to grow, collect, and convert them to ethanol, and they are not used for human food [1].

The cell wall of the plant is composed of a network of cellulose microfibrils and crosslinking glycans embedded in a highly cross-linked matrix of pectin polysaccharides. The most common additional polymer in secondary walls is lignin, a complex network of phenolic compounds [2].

Due to the complex structure and recalcitrant nature of lignocellulosic biomass, an indispensable step of its processing is pretreatment for hydrolysis [3].

As a result, of the pretreatment, complex lignocellulosic structures are converted to simple components (cellulose, hemicelluloses, and lignin) which is generally reflected by the removal of lignin, preservation of hemicelluloses, reduction of cellulose crystallinity and an increase of the material porosity [4]. The presence of lignin and hemicellulose prevents the access of hydrolytic enzymes to the surface of cellulose fibers in the technology of enzymatic hydrolysis [5]. The goal of the pretreatment process is to remove lignin and hemicellulose, reduce the crystallinity of cellulose, and increase the porosity of the lignocellulosic materials $[6]$.

Among the many methods of influencing lignocellulosic raw materials during the preliminary preparation, several are currently commercially implemented, namely steam explosion, one- and two-stage treatment with dilute acids and ammonia treatment in combination with steam treatment [7]. The process of alkaline pre-treatment of raw materials in the pulp and paper industry is a classic [8].

The main factors that determine the effectiveness of the pre-treatment process are mechanical impact, temperature, pressure, hydraulic module, process duration, the concentration of the chemical agent. Machining increases the surface area available for cellulolytic enzymes. It is proved that fine grinding of raw materials allows increasing the yield of reducing substances during its hydrolysis [9-11].

Mechanical pretreatment leads to an increase in the surface available for cellulolytic enzymes. It is proved that the fine milling of straw allows increasing the yield of reducing substances in its hydrolysis [12].

Another factor is the temperature of the pretreatment process. Increasing the temperature from 120 to $270^{\circ} \mathrm{C}$ led to greater solubilization of hemicellulose in the technology of steam explosion [13], increasing the temperature from 120 to $180^{\circ} \mathrm{C}$ led to an increase in glucose in the prehydrolyzate regardless of the concentration of sulfuric acid in preparation for hydrolysis with dilute acids [14]. A series of studies on the preliminary preparation of wheat straw is presented in [15].

It is determined that increasing the temperature of the pretreatment process with a solution of sulfuric acid, sodium hydroxide solution or hot water pretreatment leads to an increase in the degree of conversion of cellulose. The dependence of lignin yield on the temperature and processing time of wheat straw in an autoclave in $2.5 \%$ sodium hydroxide solution was studied by Asghar U, Irfan M, Iram M, et al. [16]. The results showed that the residence time for $90 \mathrm{~min}$ at $121{ }^{\circ} \mathrm{C}$ strongly affects the substrate, reaching a maximum cellulose content of $83 \%$, delignification of $81 \%$, and hemicellulose content of $10.5 \%$. 
All the above-mentioned methods of pretreatment of lignocellulosic raw materials before hydrolysis were performed with an external heat supply.

One of the ways to increase the efficiency of pre-treatment of lignocellulosic raw materials is the use of thermophysical effects that occur during the movement of a viscous fluid in rotor-pulsation apparatus [17].

Studies of the effect of temperature on the viscosity of the water-grain mixture were studied in [18]. Thermal and hydraulic characteristics of the fluid in the rotor-pulsation apparatus were given in [19]. Technical water and vegetable oil were used as model media. Experimental studies were performed on the setup, the working body of which was a rotorpulsation unit, in the range of engine speed 0-4500 rpm. However, the physicochemical properties of the model media differed from the physicochemical properties of the aqueous dispersion of plant biomass.

The aim of the study is the degree of delignification of lignocellulosic raw materials and the theoretical substantiation of its temperature increase by processing in a rotorpulsation apparatus.

To achieve this goal, it was necessary to perform the following tasks

- To determine the effect of the solid/water ratio of the aqueous suspension of wheat straw on the degree of delignification of lignocellulosic raw materials during its processing in the rotor-pulsation apparatus using alkali as a reagent;

- Determine the effect of temperature of the obtained suspension and its effect on the degree of lignin release;

- Theoretically substantiate the increase in temperature of the aqueous suspension of wheat straw during its processing in the rotor-pulsation apparatus.

\section{Materials and methods}

The raw material for the study was wheat straw with an average particle size of 100 microns.

Rotor-pulsation apparatus

The study was carried out on an experimental setup, the description and principle of operation of which are given in [20].

\section{Order of study}

A portion of straw in the amount determined by the experimental conditions was soaked in two liters of tap water. The remaining water was mixed with sodium hydroxide in an amount of $1 \mathrm{wt} . \%$. The receiving solution and the rotary pulsation apparatus were filled with the obtained solution. The required rotor speed was set. The rest of the water was added. Turned on the engine. During a certain processing time, the obtained aqueous suspension of straw circulated in a closed circuit - receiving tank - rotor-pulsation apparatus. Samples were taken at regular intervals. The solids and the filtrate were separated by filtration.

\section{Determination of lignin content}

Sulfuric acid was added to the filtrate with stirring until a $\mathrm{pH}=2$ was reached to separate the lignin from the solution, after which the suspension was filtered through a pre-weighed paper filter. The dried filter with the remaining lignin was weighed on a scale with an accuracy of $0.001 \mathrm{~g}$ [21]. 


\section{Modeling methods}

Numerical simulation of fluid flow and heat transfer in a rotor-pulsation apparatus is performed according to the method described in $[22,23]$. The flow of a viscous fluid and heat transfer in the volume of a rotor-pulsation apparatus is described by a system of Navier-Stokes differential equations together with the equation of energy conservation for fluid flow. The problem of flow and heat transfer is considered in a two-dimensional setting in a section perpendicular to the common axis of the rotor and stator. This system of equations, which describes the dynamics of fluid and energy transfer, is represented in cylindrical coordinates and has the form:

- continuity equation

$$
\frac{\partial\left(r \cdot v_{r}\right)}{\partial r}+\frac{\partial v_{\theta}}{\partial \theta}=0
$$

- momentum transfer equation

$$
\begin{aligned}
& \rho_{l}\left(\frac{\partial v_{r}}{\partial \tau}+\frac{1}{r} \frac{\partial\left(r v_{r}^{2}\right)}{\partial r}+\frac{1}{r} \frac{\partial\left(v_{r} v_{\theta}\right)}{\partial \theta}-\frac{v_{\theta}^{2}}{r}\right)=-\frac{\partial p}{\partial r}+\frac{2}{r} \frac{\partial}{\partial r}\left(\mu_{l} r \frac{\partial v_{r}}{\partial r}\right)- \\
& -\frac{2 \mu}{r^{2}}\left(\frac{\partial v_{\theta}}{\partial \theta}+v_{r}\right)+\frac{1}{r} \frac{\partial}{\partial \theta}\left\{\mu\left[\frac{1}{r} \frac{\partial v_{r}}{\partial \theta}+r \frac{\partial}{\partial r}\left(\frac{v_{\theta}}{r}\right)\right]\right\} ; \\
& \rho_{l}\left(\frac{\partial v_{\theta}}{\partial \tau}+\frac{1}{r} \frac{\partial\left(r v_{\theta} v_{r}\right)}{\partial r}+\frac{1}{r} \frac{\partial v_{\theta}^{2}}{\partial \theta}+\frac{v_{\theta} v_{r}}{r}\right)=-\frac{1}{r} \frac{\partial p}{\partial \theta}+\frac{2}{r^{2}} \frac{\partial}{\partial \theta}\left[\mu_{l}\left(\frac{\partial v_{\theta}}{\partial \theta}+v_{r}\right)\right]+ \\
& +\frac{1}{r^{2}} \frac{\partial}{\partial r}\left\{\mu\left[r \frac{\partial v_{r}}{\partial \theta}+r^{3} \frac{\partial}{\partial r}\left(\frac{v_{\theta}}{r}\right)\right]\right\} ;
\end{aligned}
$$

energy conservation equation for fluid flow

$$
C_{l} \rho_{l}\left(\frac{\partial t}{\partial \tau}+\frac{1}{r} \frac{\partial\left(r v_{r} t\right)}{\partial r}+\frac{1}{r} \frac{\partial\left(v_{\theta} t\right)}{\partial \theta}\right)=\frac{1}{r^{2}} \frac{\partial}{\partial \theta}\left(\lambda_{l} \frac{\partial t}{\partial \theta}\right)+\frac{1}{r} \frac{\partial}{\partial r}\left(\lambda_{l} r \frac{\partial t}{\partial r}\right)+\mu_{l} S^{2},
$$

where

$$
S=\left\{2\left[\left(\frac{\partial v_{r}}{\partial r}\right)^{2}+\frac{1}{r^{2}}\left(\frac{\partial v_{\theta}}{\partial \theta}+v_{r}\right)^{2}\right]+\left[\frac{1}{r} \frac{\partial v_{r}}{\partial \theta}+r \frac{\partial}{\partial r}\left(\frac{v_{\theta}}{r}\right)\right]^{2}\right\}^{0,5} .
$$

$\tau, \mathrm{c}$ - time; $\mathrm{r}, \mathrm{m}$ - radial coordinate; $\theta$ - angular coordinate; $v_{r}, \mathrm{~m} / \mathrm{s}$ - radial velocity; $v_{\theta}, \mathrm{m} / \mathrm{s}$ - tangential velocity; $p, \mathrm{~Pa}$ - pressure; $t,{ }^{\circ} \mathrm{C}$ - temperature; $C_{l}, \mathrm{~J} /(\mathrm{kg} \cdot \mathrm{K})$ - heat capacity of the liquid; $\rho_{l}, \mathrm{~kg} / \mathrm{m}^{3}$ - density of liquid; $\lambda_{l}, \mathrm{~W} /(\mathrm{m} \cdot \mathrm{K})$ - thermal conductivity of the liquid; $\mu_{l}, \mathrm{~Pa} \cdot \mathrm{s}$ - dynamic viscosity coefficient.

The last term in the right part of energy equation (4) characterizes the volumetric source of heat release in a liquid medium due to the viscous dissipation of mechanical energy.

The system of equations (1) - (5) is solved numerically in the calculation domain $r_{\min } \leq$ $r \leq r_{\text {max }} ; \theta_{0}<\theta<\theta_{0}+\Delta \theta ; r_{\text {min }}=r_{\text {in, rot }}-\Delta r ; r_{\text {max }}=r_{e x, s t}+\Delta r$, where $r_{i n, \text { rot }}$ is inner radius of the rotor; $r_{e x, s t}$ is outer radius of the stator; $\Delta r$ - width of the additional section in front of the rotor and behind the stator; $\Delta \theta-$ geometric period of working bodies of the rotor-pulsating apparatus. 
The system of equations (1) - (5) is given boundary conditions: $r=r_{\min }: t=t_{\text {in }} ; p=p_{\text {in }}$; $\frac{\partial v_{\theta}}{\partial r}=0 ; r=r_{\text {max }}: \frac{\partial t}{\partial r}=0 ; p=p_{\text {in }}-\Delta p ; v_{\theta}=0$. On the stator surfaces $v_{r}=0$ and $v_{\theta}=0$. On the rotor surfaces $v_{r}=0, \frac{v_{\theta}}{r}=\omega_{0}$, where $\omega_{0}$ is the angular velocity of the rotor rotation.

Heat transfer through the working elements of the apparatus is described by the equations:

- for the stator:

$$
C_{s} \rho_{s} \frac{\partial t}{\partial \tau}=\frac{1}{r^{2}} \frac{\partial}{\partial \theta}\left(\lambda_{s} \frac{\partial t}{\partial \theta}\right)+\frac{1}{r} \frac{\partial}{\partial r}\left(\lambda_{s} r \frac{\partial t}{\partial r}\right)
$$

- for the rotor:

$$
C_{s} \rho_{s}\left(\frac{\partial t}{\partial \tau}+\omega_{o} \frac{\partial t}{\partial \theta}\right)=\frac{1}{r^{2}} \frac{\partial}{\partial \theta}\left(\lambda_{s} \frac{\partial t}{\partial \theta}\right)+\frac{1}{r} \frac{\partial}{\partial r}\left(\lambda_{s} r \frac{\partial t}{\partial r}\right)
$$

where $C_{s}, \mathrm{~J} /(\mathrm{kg} \cdot \mathrm{K})$ - heat capacity of the material of the working elements; $\rho_{s}, \mathrm{~kg} / \mathrm{m}^{3}$ - density of this material; $\lambda_{s}, \mathrm{~W} /(\mathrm{m} \cdot \mathrm{K})$ - thermal conductivity of the material.

Boundary conditions of the fourth kind are set on the surfaces of working elements, which establish the equality of temperatures of the liquid and solid body, as well as the equality of heat flux densities transferred from the liquid to working elements.

Modeling of fluid flow and heat transfer is performed by numerical solution of the system of equations (1) - (7) and analysis of the obtained results on the distribution of velocity, pressure, and temperature in the fluid flow processed in the rotor-pulsation apparatus.

The system of equations (1) - (7) with the corresponding boundary conditions is solved by a numerical method. To do this, this system of equations is written in the finite-difference form. Thus, the system of differential equations is replaced by a system of algebraic equations, which is solved by known methods. In this case, the matrix run method, which is described in detail in [24], is used to solve the system of finite-difference equations. To implement this method, a computational algorithm in the DELPHI programming language has been developed. This algorithm allows determining the cross-sectional distributions of the calculated area of discrete values of fluid velocity, pressure, and temperature. It also provides the ability to graphically display velocity vectors and temperature isolines in the working area of the device. The application of the specified calculation algorithm can be carried out on a personal computer of medium power.

In order for the liquid to reach a temperature sufficient to carry out the necessary chemical transformations, the liquid must be repeatedly processed in a rotor-pulsation apparatus. The liquid after processing in the device enters the receiving tank through a system of pipelines. In pipelines and in the receiving tank, the liquid is partially cooled due to heat loss from the surfaces of the equipment. Heat loss also occurs directly from the surface of the device. To determine the nature of the change in time of the temperature of liquids that continuously enters the rotor-pulsation apparatus and is removed from it, the differential equation of heat balance is used which is given in [23] and has the form:

$$
\left(C_{l} \rho_{l} V_{l}+C_{\mathrm{s}} m_{\mathrm{s}}+C_{\mathrm{eq}} m_{\mathrm{eq}}\right) \frac{\partial t}{\partial \tau}=Q-\alpha_{\mathrm{ef}} F\left(t-t_{\infty}\right),
$$

where $V_{l}$, is the volume of treated fluid; $m_{s}$ - mass of the rotor-pulsation apparatus; $C_{\mathrm{eq}}, m_{\mathrm{eq}}$ - specific heat of the material of the equipment connected to the rotor-pulsation apparatus, and its total mass; $F$ is the total area of the outer surface of the rotor-pulsation apparatus and 


\section{- Processes and Equipment -}

equipment from which heat losses to the environment occur; $\alpha_{\mathrm{ef}}-$ effective heat transfer coefficient from the surfaces of the equipment; $\mathrm{t}_{\infty^{-}}$outside air temperature; $Q$ is the power of the heat source in the rotor-pulsation apparatus due to the dissipation of mechanical energy. This equation of heat balance is made under the condition that the temperature of the outer surfaces is insignificantly different from the temperature of the treated liquid.

Heat transfer from the surfaces of the equipment is carried out by natural convection and radiation. Therefore, the effective heat transfer coefficient $\alpha_{\mathrm{ef}}$ is defined as the sum of convection $\alpha_{c}$ and radiation $\alpha_{r}$ heat transfer coefficients. The coefficient for natural convection in turbulent flow near vertical surfaces is calculated by the formula given in [25]:

$$
\alpha_{\mathrm{c}}=0,15 \lambda_{a}\left(\frac{g \beta\left(t-t_{\infty}\right)}{v_{a}^{2}} \operatorname{Pr}_{a}\right)^{1 / 3},
$$

where $\mathrm{g}, \mathrm{m} / \mathrm{s}^{2}$ - acceleration of gravity; $\beta, 1 / \mathrm{K}$ - temperature coefficient of air expansion; $\lambda_{a}$ - coefficient of thermal conductivity of air; $v_{a}$ - kinematic coefficient of air viscosity; $\operatorname{Pr}_{a^{-}}$ Prandtl number for air. The radiation heat transfer coefficient is determined from the expression

$$
\alpha_{\mathrm{r}}=c_{0} \varepsilon \frac{\left(\frac{t+273,15}{100}\right)^{4}-\left(\frac{t_{\infty}+273,15}{100}\right)^{4}}{t-t_{\infty}},
$$

which follows from the law of Stefan - Boltzmann, where $\mathrm{c}_{0}=5.7 \mathrm{~W} /\left(\mathrm{m}^{2} \mathrm{~K}^{4}\right)$ - the coefficient of radiation of an absolutely black body; $\varepsilon$ - the degree of blackness of radiation heat transfer surfaces is given.

The power of the heat source $Q$ in the working volume of the apparatus can be determined both by the results of the numerical solution of the system of equations (1) - (7) and by the approximate formula:

$$
Q=\pi\left(r_{\text {вн.ст }}+r_{\text {зов.рот }}\right) \cdot h \cdot \mu\left(\omega_{0} r_{\text {зов.рот }}\right)^{2} / \delta,
$$

where $\delta=r_{\text {in st }}-r_{\text {ex rot }}-$ the magnitude of the gap between the rotor and stator; $h$ is the width of the working elements of the device. The approximate formula (11) is made under the condition that the dissipation of mechanical energy occurs only in the gap between the rotor and the stator. The solution of the nonlinear equation (8) is performed by the numerical method.

\section{Results and discussion}

Figure 1 shows the dynamics of changes in temperature of water and mixture over time in the setup with a speed of $47.75 \mathrm{rpm}$ at different solid/water ratios.

Under these processing conditions, samples were taken every 10 minutes Data on the amount of lignin extracted are given in Table 1.

Based on the data in table 1, it can be concluded that the treatment of an aqueous suspension of straw in a rotary pulsation apparatus allows you to remove up to $42 \%$ of lignin within 70 minutes under atmospheric pressure without an external supply of thermal energy.

Changing the solid/water ratio of the aqueous suspension of straw from 1:10 to 1: 5 leads to an increase in the amount of lignin released, as the temperature of the mixture increases more intensely. 


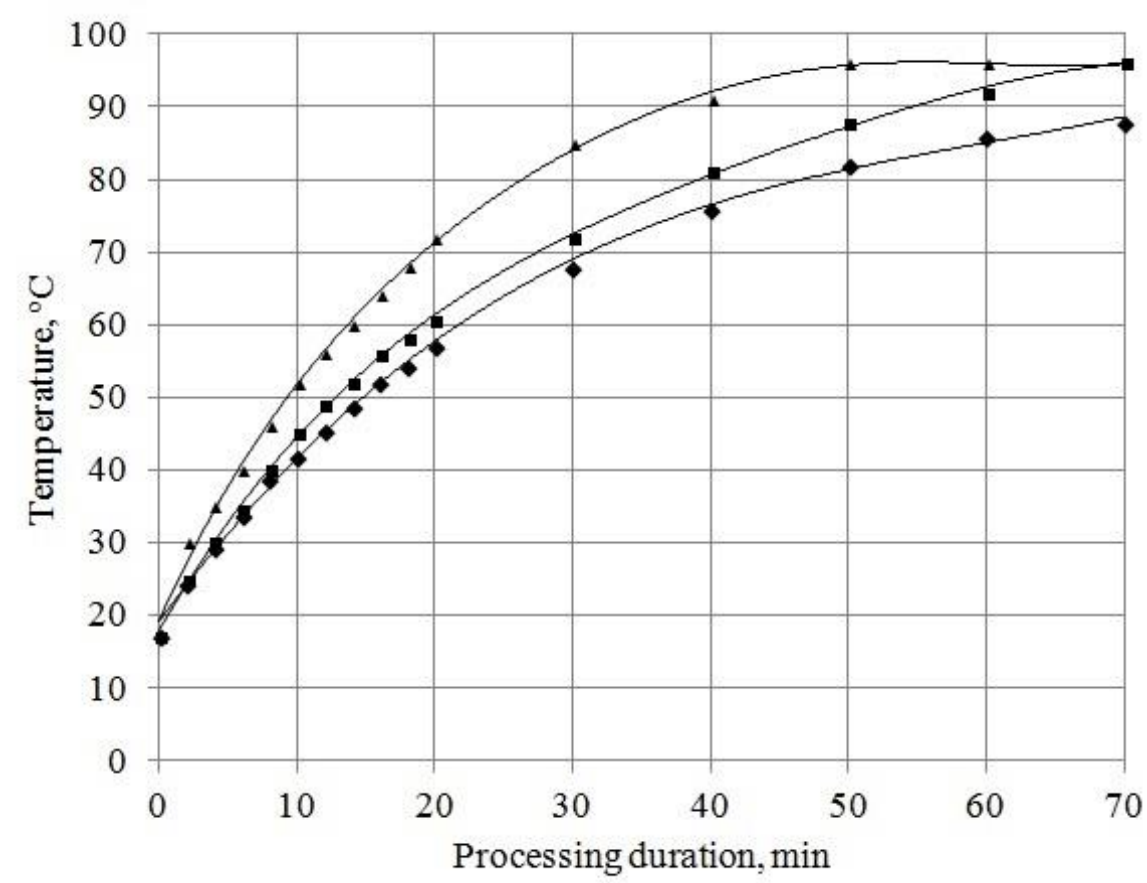

Figure 1. Dynamics of temperature change of aqueous suspension of straw in time at a solid / water ratio:

- $-1: 10 ; \Delta-1: 5 ;-$ water.

Table 1

Dependence of the amount of lignin on the duration of processing at a speed of $47.75 \mathrm{rpm}$

\begin{tabular}{|c|c|c|c|c|c|c|c|}
\hline \multicolumn{8}{|c|}{ Solid/Water ratio 1:10 } \\
\hline Sample & 1 & 2 & 3 & 4 & 5 & 6 & 7 \\
\hline Processing duration, min & 10 & 20 & 30 & 40 & 50 & 60 & 70 \\
\hline \% of the total lignin content & 10 & 18 & 25 & 32 & 38 & 41 & 42 \\
\hline \multicolumn{8}{|c|}{ Solid/Water ratio $1: 5$} \\
\hline$\%$ of the total lignin content & 18 & 29 & 36 & 45 & 50 & 55 & 58 \\
\hline
\end{tabular}

A further increase in the straw content in the mixture leads to significant energy consumption and unstable operation for the selected design of the rotor-pulsation apparatus.

Rotor speed $\omega_{0}=2 \pi \cdot 47.75 \mathrm{~s}^{-1}$. The pressure difference $\Delta p$ between the inlet and outlet cross sections of the calculated area is $5000 \mathrm{~Pa}$. The picture of fluid flow and distribution of excess temperature $\Delta t=t-t_{i n}$ in the investigated element of the working area is shown in Figure 2. 
The increase in temperature of the medium treated in the rotor-pulsation apparatus is due to the dissipation of mechanical energy in the working volume of the apparatus. As noted in $[22,23]$, the most intense dissipation occurs in the gap between the rotor and the stator, where the most significant deformation of the velocity. To find out in detail the mechanism of heating the aqueous suspension of straw in the rotor-pulsation apparatus, numerical simulation of the flow and heat transfer in this apparatus is performed. By the method of numerical solution of the system of equations (1) - (7) described above, calculations of velocity fields in temperature in the working zone of the rotor pulsation apparatus are performed for two values $\mu=0.09 \mathrm{~Pa} \cdot \mathrm{s}$ and $\mu=0.107 \mathrm{~Pa} \cdot \mathrm{s}$, which is approximately correspond to the viscosity of the aqueous dispersion of straw at a solid/water ratio of $1: 10$ and $1: 5$, respectively.
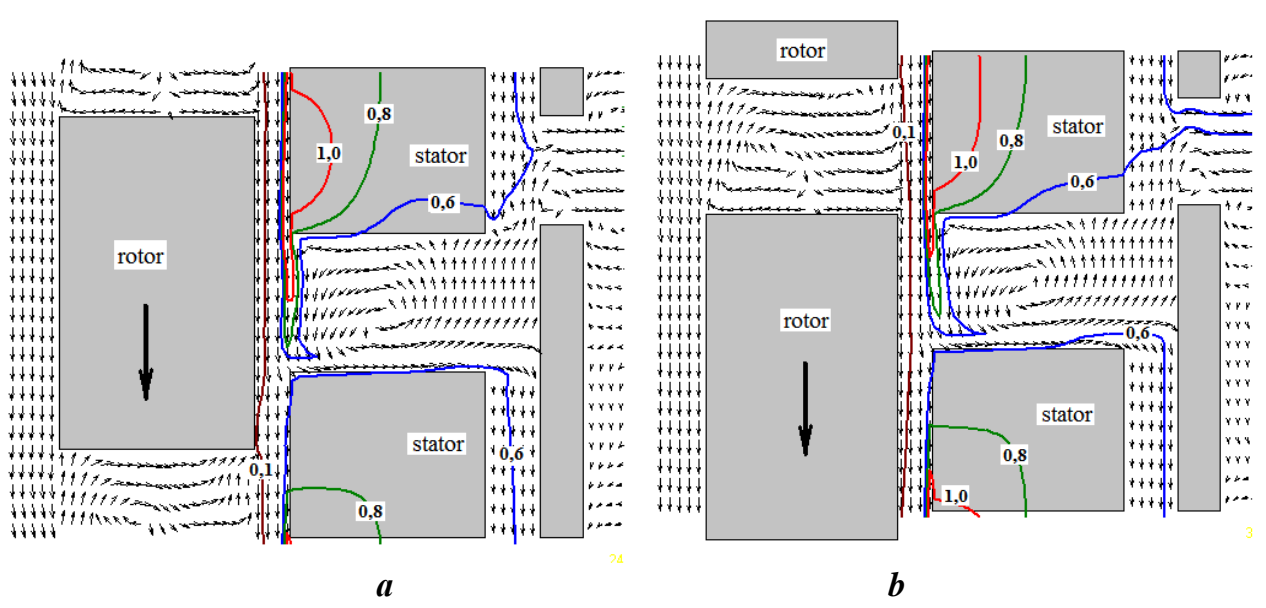

Figure 2. Velocity field and distribution of excess temperature $\Delta t$ in the working zone of the rotor-pulsating apparatus during the processing of aqueous suspension of straw: $\mathrm{a}-\boldsymbol{\mu}=0.09 \mathrm{~Pa} \cdot \mathrm{s} ; \mathrm{b}-\boldsymbol{\mu}=0.107 \mathrm{~Pa} \cdot \mathrm{s}$

As can be seen from Figure 2, the most significant overheating of the fluid occurs in the gap between the rotor and the stator near the inner surface of the stator, where the most intense heat dissipation occurs due to the dissipation of mechanical energy. From the results of numerical simulation, it follows that the maximum overheating of the liquid in the gap for one period of rotor rotation is $\Delta t_{\max }=1.9{ }^{\circ} \mathrm{C}$ at $\mu=0.09 \mathrm{~Pa} \cdot \mathrm{s}$ and $\Delta t_{\max }=2.2^{\circ} \mathrm{C}$ at $\mu=0.107$ $\mathrm{Pa} \cdot \mathrm{s}$. The average excess temperature of the treated liquid in the rotor-pulsation apparatus outlet is $\Delta t=0.44 \mathrm{oC}$ at $\mu=0.09 \mathrm{~Pa} \cdot \mathrm{s}$ and $\Delta t=0.53^{\circ} \mathrm{C}$ at $\mu=0.107 \mathrm{~Pa} \cdot \mathrm{s}$.

According to the results of solving equation (8), the change in time of the temperature of the aqueous suspension of straw having a volume of 101 is determined during its processing in the rotor-pulsation apparatus. The total heat transfer surface is $\mathrm{F}=2.8 \mathrm{~m}^{2}$. Rotor-pulsation apparatus and additional equipment made of stainless steel.

The solution of equation (8) is performed provided that the air temperature $t_{\infty}$ and the initial temperature of the liquid are equal to $20^{\circ} \mathrm{C}$.

In fig. Figure 3 shows the dependences of the temperature of the aqueous suspension of straw on the processing duration obtained by solving the results of equation (8) using expression (11). The results were obtained for $\mu=0.09 \mathrm{~Pa} \cdot \mathrm{s}$, which corresponds to a solid / 
water ratio of $1: 10$, and for $\mu=0.107 \mathrm{~Pa} \cdot \mathrm{s}$, which corresponds to a $1: 5$ ratio. The solid lines reflect the results of the numerical solution of equation (8), and the points - the results of experimental studies shown in Figure 2.

The figure shows that when processed for $60 \mathrm{~min}$. the aqueous suspension of straw with a solid / water ratio of $1: 10$, its temperature rises from $20^{\circ} \mathrm{C}$ to $87.5^{\circ} \mathrm{C}$. If the specified ratio is $1: 5$, then during the same time the aqueous suspension is heated to $97.7^{\circ} \mathrm{C}$. This indicates the possibility and feasibility of using for heating raw materials intended for hydrolysis, rotorpulsation apparatus.

Figure 3 also shows the comparison of the calculated results with the experimental data. As can be seen from the figure, the agreement between the calculated and experimental results is quite satisfactory.

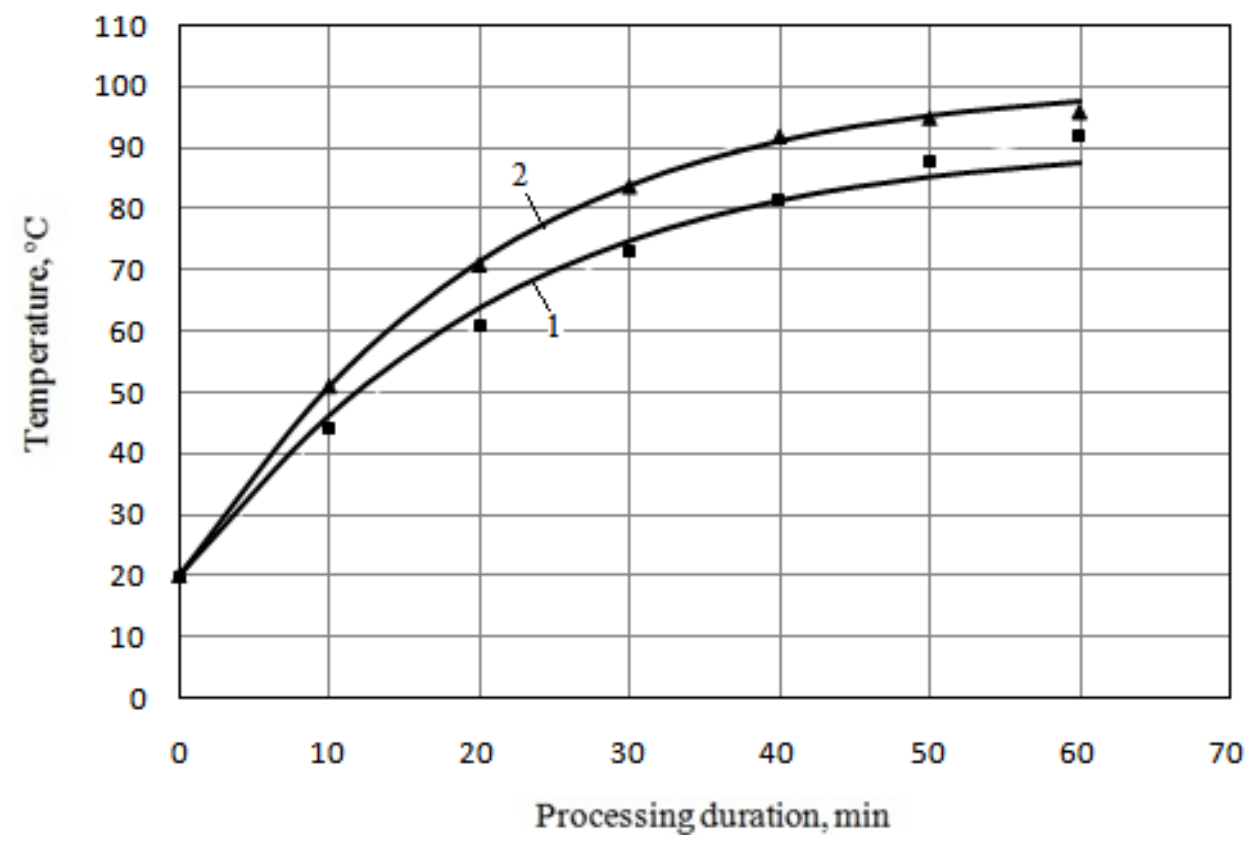

Figure 3. Changes in time of temperature of aqueous dispersion of straw during its processing in rotor-pulsation apparatus at ratios solid/water 1:10 (1) and 1:5 (2).

Solid lines - the results of calculations; points - the results of experiments.

\section{Conclusion}

According to the results of computational and experimental studies, it is established that to heat the aqueous dispersion of straw to a temperature at which lignin is intensively released, it is possible to use rotary pulsation devices without external heat supply. It is determined that the change of the hydraulic module leads to an increase in lignin yield. 


\section{References}

1. Site of U.S. Department of Energy. Alternative Fuels Data Center, Available at: https://afdc.energy.gov/fuels/ethanol_feedstocks.html

2. Alberts B., Johnson A., Lewis J. et al. (2002), Molecular Biology of the Cell. 4th edition, Garland Science, New York.

3. Liu H., Zhang Y.X., Hou T., Chen X., Gao C., Han L., Xiao W. (2018), Mechanical deconstruction of corn stover as an entry process to facilitate the microwave-assisted production of ethyl levulinate, Fuel Process. Technol., 174, pp. 53-60, DOI: 10.1016/j.fuproc.2018.02.011.

4. Kucharska K, Rybarczyk P, Hołowacz I, Łukajtis R, Glinka M, Kamiński M. (2018), Pretreatment of Lignocellulosic Materials as Substrates for Fermentation Processes, Molecules, 23(11), pp. 2937, DOI: 10.3390/molecules23112937.

5. Ladeira Ázar R.I.S., Bordignon-Junior S.E., Laufer C., Specht, J., Ferrier D., Kim D. (2020), Effect of Lignin Content on Cellulolytic Saccharification of Liquid Hot Water Pretreated Sugarcane Bagasse, Molecules, 25(3), pp. 623, Available at: DOI: 10.3390/molecules25030623.

6. Kumar Parveen, Barrett Diane M., Delwiche Michael J., and Stroeve Pieter (2009), Methods for Pretreatment of Lignocellulosic Biomass for Efficient Hydrolysis and Biofuel Production Ind, Eng. Chem. Res., 48(8), pp. 3713-3729, Available at: DOI: 10.1021/ie801542g.

7. Valdivia M., Galan J.L., Laffarga J., Ramos J.L. (2016), Biofuels 2020: Biorefineries based on lignocellulosic materials. Microb Biotechnol, 9(5), pp. 585-94, DOI: 10.1111/1751-7915.12387.

8. Xu H., Li, B., \& Mu X. Review of Alkali-Based Pretreatment To Enhance Enzymatic Saccharification for Lignocellulosic Biomass Conversion (2016), Industrial \& Engineering Chemistry Research, 55(32), pp. 8691-8705, DOI: 10.1021/acs.iecr.6b01907.

9. Nurtdinov R.M., Valeeva R.T., Mukhachev S.G., Kharina M.V. (2011), Predvaritelnaia obrabotka rastitelnogo syria i otkhodov selskokhoziaistvennogo proizvodstva s tseliu povysheniia vykhoda redutsiruiushchikh veshchestv, Vestnik Kazanskogo tekhnologicheskogo universiteta, 9, pp. 264-267.

10. Hendriks ATWM, Zeeman G. (2009), Pretreatments to enhance the digestibility of lignocellulosic biomass, Bioresour Technol, 100(1), pp. 10-18.

11. Florian Monla, Cecilia Sambusiti, and Abdellatif Barakat (2019), Comparison of Dry Versus Wet Milling to Improve Bioethanol or Methane Recovery from Solid Anaerobic Digestate, Bioengineering, 6(3), p. 80, Available at: DOI: 10.3390/bioengineering6030080.

12. Barakat A., Mayer-Laigle C., Solhy A., Arancon R.A.D., de Vries H., Luque, R. (2014), Mechanical pretreatments of lignocellulosic biomass: towards facile and environmentally sound technologies for biofuels production, RSC Advances, 4(89), pp. 48109-48127, DOI: 10.1039/C4RA07568D.

13. Duff S. J. B., Murray W. D. (1996), Bioconversion of forest products industry waste cellulosics to fuel ethanol: A review. Bioresour. Technol., 55, pp. 1-33. DOI: 10.1016/0960-8524(95)00122-0.

14. Redding Arthur P., Wang Ziyu, Keshwani Deepak R., and Cheng Jay J. (2011), High temperature dilute acid pretreatment of coastal Bermuda grass for enzymatic hydrolysis. Biological Systems Engineering: Papers and Publications, 204, pp, 1415-1424, DOI: 10.1016/j.biortech.2010.09.053. 
15. Zheng Q., Zhou T., Wang Y. et al. (2018), Pretreatment of wheat straw leads to structural changes and improved enzymatic hydrolysis. Scientific Reports, 8(1).1321 doi:10.1038/s41598-018-19517-5.

16. Asghar, U., Irfan, M., Iram, M., et al. (2015), Effect of alkaline pretreatment on delignification of wheat straw. Nat Prod Res.9(2), pp. 125-131. doi:10.1080/14786419.2014.964712.

17. Dolinskij A.A., Ivanickij, G.K. (2008), Teplomassoobmen i gidrodinamika $v$ parozhidkostnyh dispersnyh sredah. Teplofizicheskie osnovy diskretno-impulsnogo vvoda energii, Naukova Dumka, Kyiv.

18. Obodovich A N Lymar A Iu. ( 2014), Issledovanie vliianiia temperatury na viazkost vodozernovoi smesi pri obrabotke $\mathrm{v}$ rotorno-pulsatsionnom apparate (RPA), Promyshlennaia teplotekhnika, 36(6), pp. 57-61.

19. Pirozhenko I.A. (2004), Eksperimentalnye issledovaniia teplovikh i gidrodinamicheskikh kharakteristik zhidkosti v rotorno-pulsatsionnom apparate, Promyshlennaia teplotekhnika, 26(6), pp. 106-113.

20. Larysa A. Sablii, Oleksandr M. Obodovych, Vitalii V. Sydorenko, Tamila,V. Sheyko (2019), Study of wheat straw delignification in a rotary-pulsation apparatus. Acta Periodica Technologica, 51, pp. 103-111, www.tf.uns.ac.rs/download/nauka/publikacije/acta/apteff-51-2020.pdf

21. Obolenskaya A.V., Elnickaya Z.P., Leonovich A.A. (1991), Laboratornye raboty po himii drevesiny i cellyulozy: Uchebnoe posobie dlya vuzov, Ekologiya, Moscow.

22. Basok B.I., Davydenko B.V., Obodovich A.N., Pirozhenko I.A. (2006), Dissipaciya energii v aktivnoj zone rotorno-pulsacionnogo apparata, Dopovidi NAN Ukrainy, 12, pp. 81-87.

23. Basok B.I., Davydenko B.V., Avramenko A.A., Pirozhenko, I.A. (2012), Gidrodinamika, teploobmen i effekty drobleniya vo vrashchatel'no-pul'siruyushchikh potokakh, Vydavnycho-polihrafichnyi tsentr "Ekspres", Kyiv.

24. Davydenko B.V. (2008), Metod matrichnoy progonki dlya resheniya setochnykh uravneniy gidrodinamiki, Vostochno-Yevropeyskiy zhurnal peredovykh tekhnologiy, 5/5(35), pp. 7-11.

25. Mikheyev M.A., Mikheyeva I.M. (1973), Osnovy teploperedachi, Energiya, Moscow. 